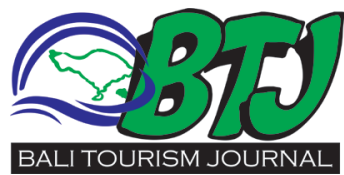

\section{Experience Bali in Japan: A Short Trip to Nasu Highland}

\author{
Akinori Wada ${ }^{1}$
}

ABSTRACT

COVID-19 outbreak around the world made overseas travel almost impossible. Thus, for this summer holiday, Nasu may be opted as destination to spend freetime with family. Located in the northeast of Tochigi prefecture, Nasu is a rural town set in a vast mountain range. The area is famous for its attractions such as onsen, themed park and winter sports. There is also a historical sightseeing Sessho-seki, Nasu Yumoto Onsen, and Imperial villa. Those who wish to experience overseas experience may visit the mini theme park of the Asian old bazaar, located on Nasu Road in Tsumujigadaira Yumoto, Nasu Town. There we can find shopping complexes with Asian themes such as Vietnam, India, Nepal, Thailand and Bali. Ubudo Restaurant, a restaurant decorated with Balinese architecture, offers a variety of Balinese culinary specialties. The Balinese vibe is strongly-felt right after entering the restaurant's Candi Bentar gate, which perfected the dining experience in Bali. The visitor may also visit many favorite spots such as Nasu ropeway, Minamigaoka Bokujo, the Monkey Park, the Museum of Cars, the Teddy Bear Museum, and the Animal Kingdom tourist park that should not be missed.
PT Pertamina (PERSERO) East Asia Representative;

Song.of.eternity@gmail.com

Editor:

Ida Bagus Ngurah Tri Pramana
Received : 2020-09-11 Accepted : 2020-11-20 Published: 2020-12-05

Keyword: Nasu, Tochigi, Highland, Holiday

Cite This Article: Wada, A. 2020. Experience Bali in Japan: A Short Trip to Nasu Highland. Bali Tourism Journal (BTJ) 2020, 4(1): 49-53. D0I : 10.36675/btj.v4i1.49

\section{INTRODUCTION}

COVID-19 outbreak around the world made overseas travel almost impossible. Thus for this summer holiday, Nasu may be opted as destination to spend freetime with family. Located in the northeast of Tochigi prefecture, Nasu is a rural town set in a vast mountain range. The Naka River flows through the southwestern part of the city and the Kurokawa River through the northeast. Mostly, its area lies within the boundaries of the Nikko National Park. This area's uniqueness is its position on the volcanic zone; thus, it has many hot springs or Onsen. For example, in the Yumoto area, there are around seven hot springs that attract local people and tourists to experience them. Another plus point of the Nasu area is its position that is surrounded by mountains. It is indeed a gem for winter sports lovers. The Nasu Plateau spreads across the northernmost tip of Tochigi Prefecture. There is Mount Nasu, a complex group of volcanoes with several peaks, on the border between Tochigi Prefecture and Fukushima Prefecture. This plateau spreads to the south and southeast of the summit with an area of about $20 \mathrm{~km} 2$. Its highest peak is Sanbonyari, with a height of 1,917 meters above sea level, and the second-highest is Chausu, with a height of 1,915 meters above sea level. Mount Nasu is an excellent place for hiking, skiing and snowboarding. There are even famous ski resorts around the slopes of the mountain. It can be said that the Nasu economy's pulse depends on its tourism attractions, both hot spring tourism and ski resorts. ${ }^{1}$

\section{PROFILE OF NASU}

Ashino Town, Nasu Village, and Iouno were formed within the Nasu District and inaugurated on 1 April 1889 to create a modern municipal system. Then, on 3 November 1954, the three municipalities merged to form Nasu City. The city is part of the Tochigi $3^{\text {rd }}$ district of the Japanese Diet's lower house in national politics. Nasu has a mayoral form of government with a directly elected mayor, a unicameral city council with thirteen members. Nasu, together with the city of Nasushiobara, each contributed four members to join the Tochigi Prefectural Assembly. As for the population, based on the recent Japanese census in August 2020, the city is populated by 24,851 spread in 10.400 households. Its population density is estimated at 67 people per $\mathrm{km}^{2}$ on 372.34 square kilometers area. ${ }^{1}$ Nasu is considered a region with a relatively stable population growth rate for the last 40 years. $^{3}$

Nasu City is blessed with a humid continental climate with an annual temperature around $11.4^{\circ} \mathrm{C}$. The prefecture experiences warm summers, but it turns into a cold area with occasional heavy snowfall 


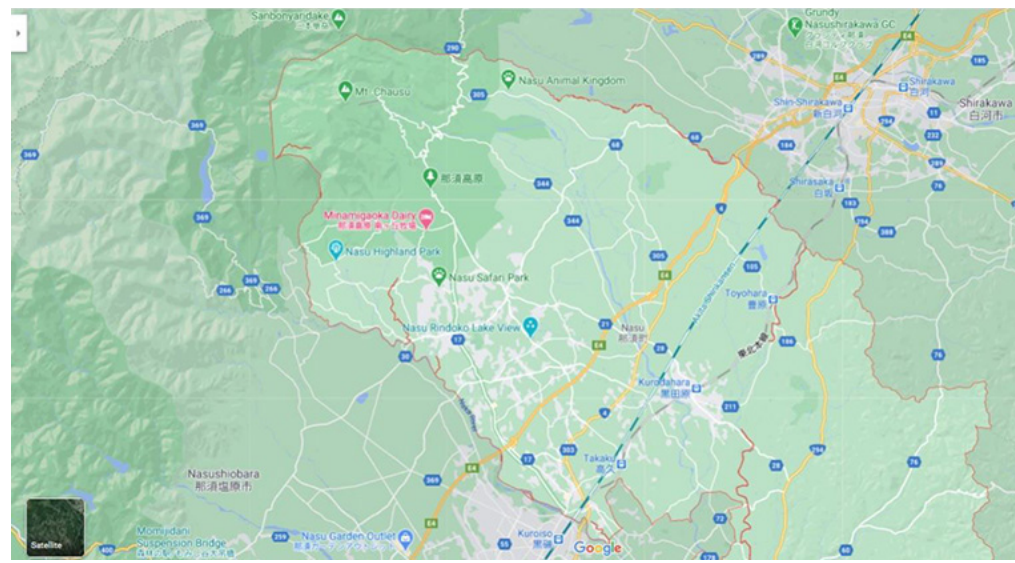

Figure 1. Map of Tochigi Prefecture ${ }^{2}$

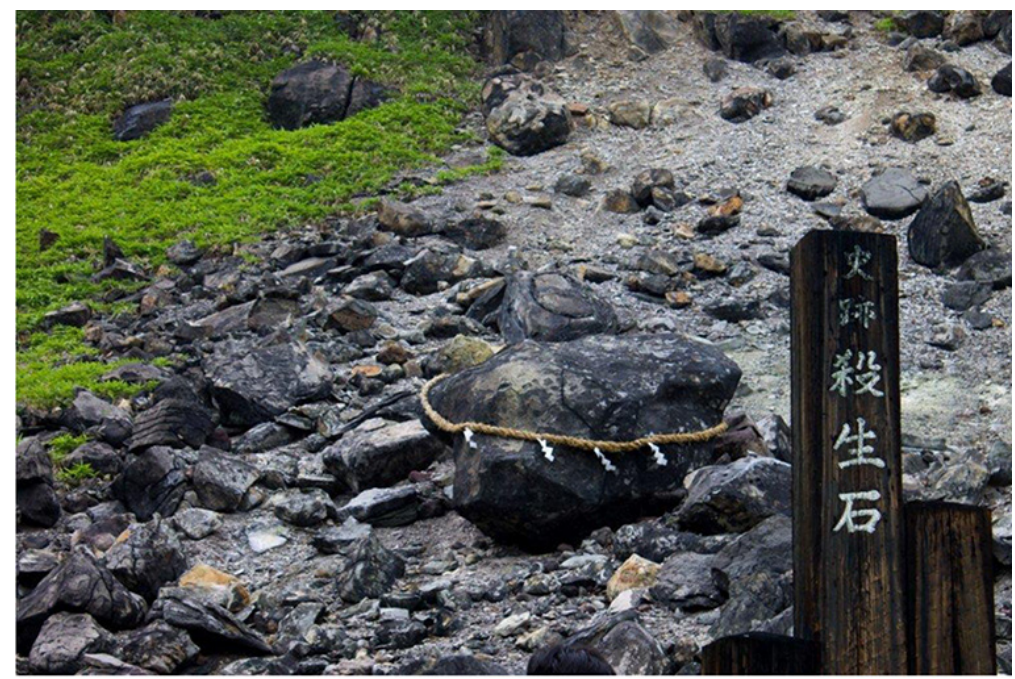

Figure 2. When the Nine-tailed Fox was defeated by the famous warrior Miura-no-suke, the fox demon changed its form into a boulder Sessho-Seki or Killer Stone ${ }^{5}$

in winter. The annual rainfall average is recorded at $1406 \mathrm{~mm}$, with September as the wettest month. The average highest temperature is recorded at around $24.0^{\circ} \mathrm{C}$ in August. While in January, it is around $-0.2^{\circ} \mathrm{C} .{ }^{4}$ When visiting Nasu, tourists are advised to use four-wheeled vehicles because the area's contours are broad and hilly. By train, NasuShiobara is the closest station on the JR Tohoku Shinkansen line. About 75 minutes from Tokyo or Sendai area. Here, we can find free buses ready to take passengers to several hot spring resorts in the vicinity. Alternatively, the alternative route is from Kuroiso Station, which is about 10 minutes from the main JR Tohoku line.

\section{HISTORIC LANDMARK, THE SESSHO- SEKI}

The Nasu area's iconic landmark is the Killer Stone or Sessho-seki. Sessho-seki is a historic area famous for its thousands of scattered volcanic rocks. The area, located about $0.5 \mathrm{~km}$ north of Shikanoyu, is classified as a dangerous area because it emits toxic volcanic gases. Due to its nickname as a killer stone, the poisonous gas that gushes out makes the surrounding area uninhabitable for small animals but is less dangerous to humans. The large rock is thought to have been there for centuries. Its existence is closely related to one of the famous Japanese mythologies.

In Japanese mythology, in the $12^{\text {th }}$ century, the $74^{\text {th }}$ Emperor of Japan, the emperor Toba, fell in love with an intelligent, gorgeous lady named Tamamo no Mae. As a result of their relationship, the king was gradually weakened and became seriously ill. One day, an astrologer named Abe no Yasuchika learned of the woman's true identity after examining the king's condition. The astrologer mentioned that Tamamo no Mae was a Nine-tailed fox in disguise. The demon was full of evil intentions. In a different version, it was said that the demon cooperated with an evil daimyo to kill Emperor Konoe, Emperor Toba's son, to seize his throne. Realized that her disguise had been exposed, Tamamo no Mae fleed from the palace. The king ordered his men to chase and execute the fox demon on the Nasu plain. The king sent Kazusa-no-suke and Miura-no-suke as told in the Otogi-zōshi tale. When the Nine-tailed Fox was defeated by the famous warrior Miurano-suke, the fox demon changed its form into a boulder Sessho-seki.

Since the aftermath, the Sessho-Seki has been believed to be haunted by the evil Nine-tailed fox. No man dared to approach the rock. Many reported that any living creatures trying to approach or pass through the area around the Sessho-seki were mysteriously dead. The terror of the Nine-tailed fox spirit finally put to an end in the seventeenth century. In 1653, a Buddhist priest named Gennō Shinshō rested near the stone and was threatened by Tamamo-no-Mae. Genno pleaded to the Ninetailed fox spirit leave the area and promised her to perform a Buddhist ritual to relieve her spirit. In the end, Tamamo-no-Mae relented and vowed never to haunt the rock again. To visit the SesshoSeki, a walking path has been constructed from Shikanoyu to the sacred stone site. There is also an Onsen Shrine on the road that will be traversed on the way by the tourist. From the boulder site, visitor can continue their travel further.?

\section{NASU HIGHLAND ATTRACTIONS}

Apart from the Sessho-Seki, the Nasu area has several amusement parks located on the Nasu plateau. Each amusement park has its distinctive 


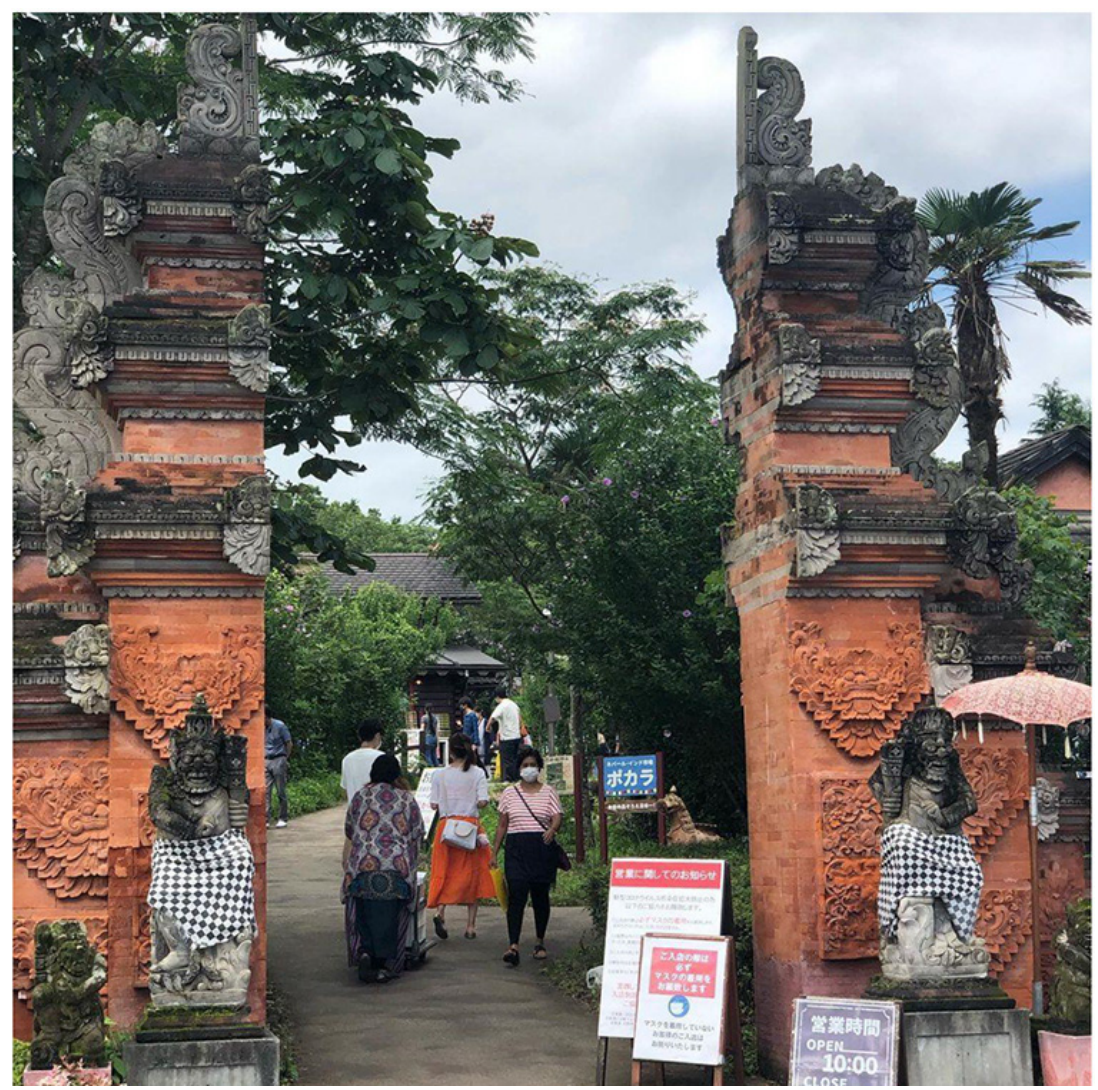

Figure 3. Candi Bentar at Ubudo Restaurant ${ }^{9}$
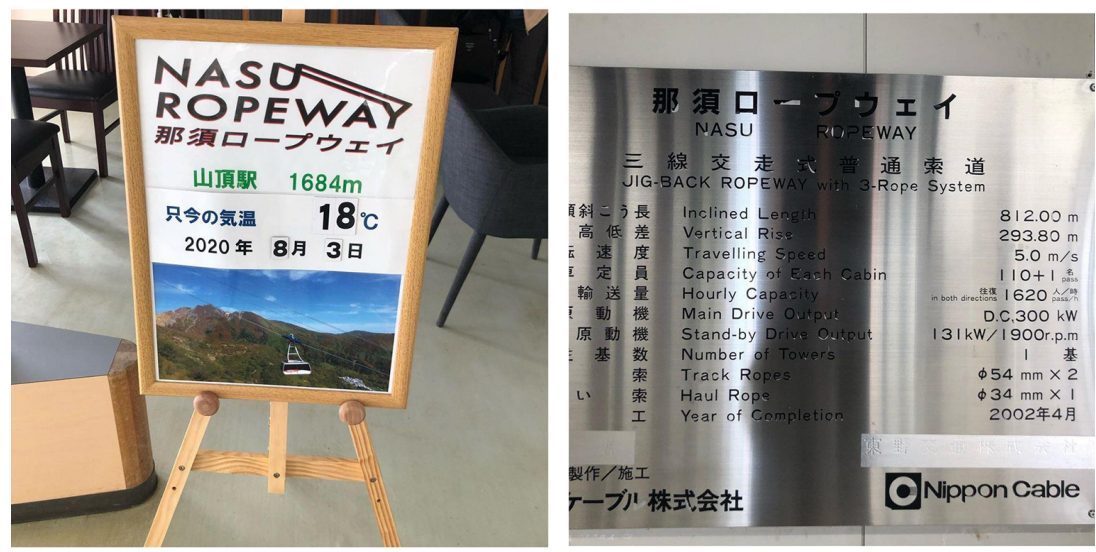

Figure 4. Nasu Ropeway Description Board

characteristics. The Nasu Kogen (Nasu Plateau) region is home to many amusement parks. The largest themed-park in the vicinity is Nasu Highland Park. This largest park in Tochigi's location is about five $\mathrm{km}$ southwest of the famous hot spring resort Nasu Yumoto. The park is popular for its adrenaline roller coasters, set in the mountainous Nasu region. There is also a Ferris wheel, an indoor roller coaster, a fishing pond, a giant carousel, a haunted castle, and more than 40 attractions available. Despite well known for its thrilling attractions yet the themed-park remains family-oriented. Thus the visitors can choose either to enjoy its child-friendly rides or to experience the adrenaline-pumping rides. Local favors the park due to its less packed compares to other large amusement parks in Japan. Many tree-sheltered areas are available, make the park is suitable as a picnic spot for a family getaway on long holidays. ${ }^{8}$

Unique experiences are also offered at the mini theme park Asian old bazaar, located on Nasu Road in Tsumujiga-daira Yumoto, Nasu Town. There we can find shopping complexes with Asian themes shops such as Vietnam, India, Nepal, Thailand and Bali. The most exciting spot is Ubudo Restaurant, a restaurant decorated with Balinese architecture with various mouth-watering Balinese culinary specialties. The Balinese vibe is strongly-felt right after entering the Candi Bentar gate of the restaurant. It perfected the dining experience on the island of the Gods. ${ }^{10}$

Other great attractions worth visiting are the Monkey Park, Museum of Cars, the Teddy Bear Museum, Rindo Lake, and the Animal Kingdom tourist park. If the visitor wishes to experience the excitement of being closer to cats and dogs, Nasu Animal Kingdom would be a perfect choice. Its location is about $4.5 \mathrm{~km}$ northeast of the Nasu Yumoto hot spring resort. At the Animal Kingdom Tourism Park, visitors can rent dogs hourly. There are also dog shows and New Zealand's sheep shearing. For beer lovers, they can visit the Nasu Kogen Brewery. Here, tourists will be offered dozens of locally made beer variants with distinctive flavors that should not be missed. ${ }^{11}$

About $3.5 \mathrm{~km}$ south of the Nasu Yumoto hot spring resort, there is the Nasu Safari Park. The zoo is conserving about seventy types of African animals such as lions, elephants, giraffes or zebras. There are also several collections of exotic albino animals such as "white lion" and "white ostrich." Here, visitors can observe wildlife through park buses or cars. From Nasu Safari Park, approximately $3.5 \mathrm{~km}$ to the east, there is the Rindo Lake Family Park, a park with a Switzerland-themed atmosphere. There are many interesting child-friendly attractions around Lake Rindo. This location is suitable for families that wish to spend their free time with children.

At an altitude of approximately 300 meters, We can find the Tohoku Expressway, Tohoku Shinkansen, and the JR Tohoku Line along the highlands' southeast edge. The plateau has a cool temperature, with the average high temperature in the middle of summer is around 25 degrees C. When it is spring, azalea flower beds will spoil its beholder. In autumn, the charm of fallen leaves captivates the heart, while in winter, ski tours and hot springs are most desirable. Here tourists can 


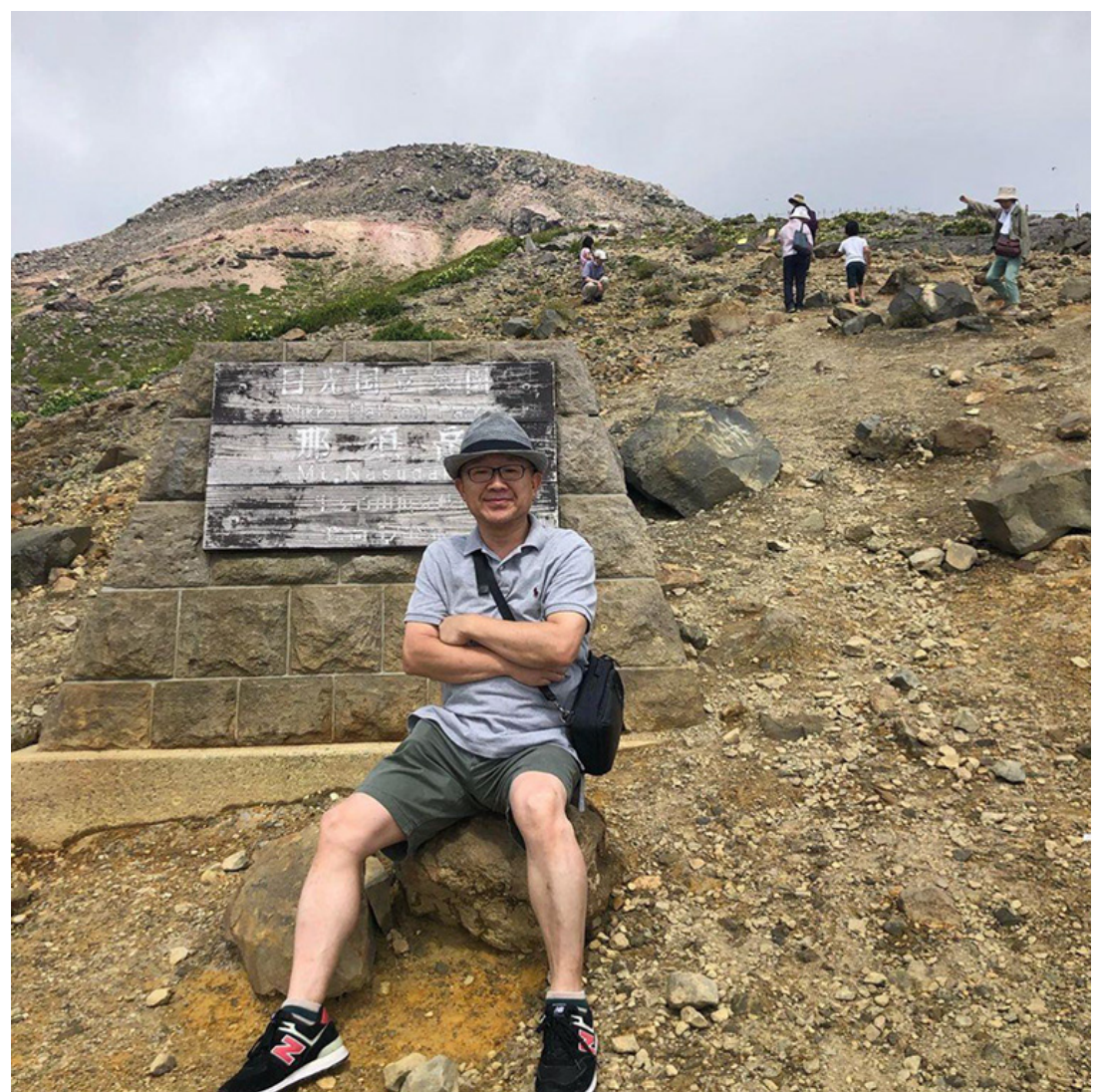

Figure 5. at the peak of Mountain Nasudai

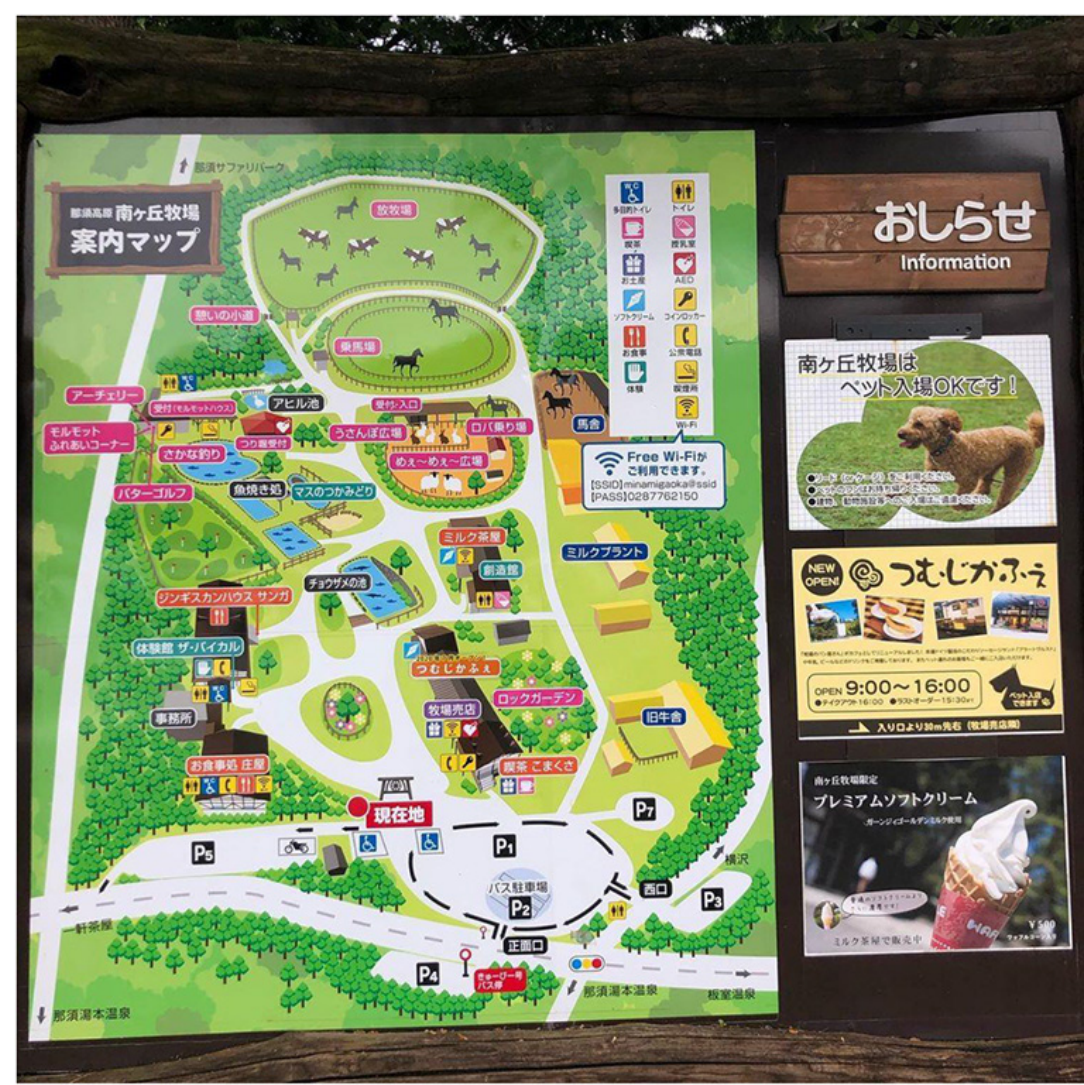

Figure 6. Minamigaoka Bokujo, a Ranch area that breeds several cows, such as Guernsey cattle. ${ }^{14}$ choose how to spend their vacation time because there are many lovely resorts, small hotels, inns, villas and restaurants that serve tasty foods. Visitors can also find the Nasu Imperial Villa, which is well-known in Japan. The building is a residence belonging to the Japanese Imperial Family. For hiking lovers, do not miss the Nasu Ropeway. This suspension bridge operates from around March to November to connect from the Chausu mountain slope to its peak. ${ }^{13}$

To the southeast of Mount Nasu, we can find Nasu onsen-Kyo or Nasu onsen resorts. This location is a tourist center about two to five kilometers from the top of the mountain. Located at an altitude of 1000 meters, we can find a hot spring Nasu Yumoto, which has existed since the seventh century. The public bath gets its water flow from an old hot spring called Shikanoyu, located around the resort's northern part. Its hot water character tends to be acidic with a cloudy color. Shikanoyu provides two bathing areas, one mixed and one for women..$^{15}$ Heading south from the Nasu Yumoto onsen resort is Minamigaoka Bokujo. This Ranch area breeds several cows, such as Guernsey cattle. This location is open to the public who wish to visit and experience ranch life. Attractions offered, including dairy and dairy products tasting tour, or meat the farm meat shop. Visitors can also experience donkeys or horses riding while enjoying the ranch atmosphere, away from the city's hustle and bustle. ${ }^{16}$

\section{CONCLUSION}

Nasu, in Tochigi prefecture, is a rural town. The area is famous for its attractions such as onsen, themed park and winter sports. There is also a historical sightseeing Sessho-seki, Nasu Yumoto Onsen, and Imperial villa. Those who wish to experience overseas experience may visit the mini theme park of the Asian old bazaar, located on Nasu Road in Tsumujiga-daira Yumoto, Nasu Town. There we can find shopping complexes with Asian themes such as Vietnam, India, Nepal, Thailand and Bali. Ubudo Restaurant, a restaurant decorated with Balinese architecture, offers a variety of Balinese culinary specialties. The Balinese vibe is stronglyfelt right after entering the restaurant's Candi Bentar gate, which perfected the dining experience in Bali. The visitor may also visit many favorite spots such as Nasu ropeway, Minamigaoka Bokujo, the Monkey Park, the Museum of Cars, the Teddy Bear Museum, and the Animal Kingdom tourist park that should not be missed. 


\section{REFERENCES:}

1. Nasu Town Official site. 2020. Available at URL: https:// www.town.nasu.lg.jp/index1.html.

2. Image taken from Google Maps 'Nasu - Tochigi. 2020. Available at URL: https://www.google.com/maps/place/ Nasu,+Nasu+District,+Tochigi,+Japan/@37.0580297,140 $.0771812,12 \mathrm{z} /$ data $=! 4 \mathrm{~m} 5 ! 3 \mathrm{~m} 4 ! 1 \mathrm{~s} 0 \times 602028 \mathrm{cf} 97 \mathrm{f} 1716 \mathrm{f}: 0 \mathrm{x}-$ 3a7b37432bdc9ccd!8m2!3d37.0197825!4d140.1209869.

3. The population of Tochigi prefecture. citypopulation[dot] de. 2020. Available at URL: https://www.citypopulation. de/en/japan/tochigi/.

4. NASU ClIMATE (Japan). Climate-Data[dot]org. 2020. Available at URL: https://en.climate-data.org/asia/japan/ tochigi/nasu-54247/.

5. Image from DA Brown 'Nasu's Sessho-Seki or Killing Stone - Nasu's link to Japanese mythology'. Japan Travel. 2015. Available at URL: https://en.japantravel.com/ tochigi/nasu-s-sessho-seki-or-killing-stone/17266.

6. Goff J. Foxes in Japanese culture: Beautiful or beastly? Japan Quarterly. 19971 April;44(2):66.

7. Basho M. The narrow road to the deep north and other travel sketches. Penguin UK; 202027 February.

8. Nasu Highland Park, Nasu-machi. inspirock. 2020. Available at URL: https://www.inspirock.com/japan/nasumachi/nasu-highland-park-a654162883.
9. Image of Ubudo Restaurant by Akinori Wada. 2020. Private Collection.

10. https://japantravel.navitime.com/en/area/jp/spot/02301$2900227 /$.

11. Nasu Highland Park Official Site. 2020. Available at URL: https://coasterpedia.net/wiki/Nasu Highland Park.

12. Image of Nasu Ropeway by Akinori Wada. 2020. Private Collection.

13. Nasu highland [那須高原]. travel-around-japan[dot]com. 2020. Available at URL: http://www.travel-around-japan. com/k36-35-nasu.html.

14. Image of Minamigaoka Bokujo by Akinori Wada. 2020. Private Collection.

15. Nasu onsen (Shikanoyu). Royal Resort Nasu. 2020. Available at URL: https://www.nasukogen.org/nasuonsen/.

16. Nasu Highland Park. mystays[dot]com. 2020. Available at URL: https://www.mystays.com/en-us/attractions-nasuhighland-park-tochigi-japan/

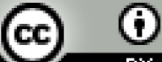

his work is licensed under a Creative Commons Attribution 